American University Washington College of Law

Digital Commons @ American University Washington College of

Law

Articles in Law Reviews \& Other Academic Journals

Scholarship \& Research

1991

Per Se Rules in the Antitrust Analysis of Horizontal Restraints

Jonathan Baker

Follow this and additional works at: https://digitalcommons.wcl.american.edu/facsch_lawrev

Part of the Antitrust and Trade Regulation Commons 


\section{Per se rules in the antitrust analysis of horizontal restraints}

BY JONATHAN B. BAKER*

Restrictions among competitors, or horizontal restraints, raise the specter of the very trusts that the antitrust laws were enacted to prevent. They call forth an image of collusion among rivals to restrict output and raise price, still the paradigm case of an unlawful restraint on trade. But today this image competes with a second, more benign picture: of firms working together to reduce production costs, to lower consumer search or transaction costs, and to create new products. As Langenfeld and Morris ${ }^{1}$ empha-

* Director of Litigation Studies, Economic Analysis Group, Antitrust Division, United States Department of Justice.

AUTHOR'S NOTE: The views expressed do not necessarily reflect those of the Department of Justice. These remarks were originally prepared as a discussion of papers by Paul T. Denis, and James A. Langenfeld and John R. Morris, at the 1990 meeting of the Western Economic Association. The author is indebted to Paul Denis and Bobby Willig for helpful discussions.

1 Langenfeld \& Morris, Analyzing Agreements Among Competitors: What Does the Future Hold? 36 ANTrTRust BuLL. 651 (1991). Langenfeld and Morris' primary interest is to demonstrate that competing members of a trade association can achieve market power through association rules that merely raise marginal costs for all association members, even though those rules do not directly affect price. While each competitor experiences higher costs, each can profit when the collective enforcement of the association

○ 1992 by Federal Legal Publications, Inc. 
size, often both images are grounded in reality. Accordingly, in reviewing horizontal restraints, courts are frequently forced to weigh the harm from any exercise of market power against the benefits of any efficiencies generated.

This task is structured by a set of legal rules: some practices are held illegal per se, and others are analyzed for their reasonableness. Paul Denis ${ }^{2}$ interprets the recent Supreme Court decisions reviewing horizontal restraints as preserving a sharp distinction between these categories. In contrast, other commentators argue that the Supreme Court discarded the per se rule entirely in Broadcast Music, Inc. v. Columbia Broadcasting System, Inc. $(B M I)^{3}$ and National Collegiate Athletic Association v. Board of Regents $(N C A A),{ }^{4}$ and, in consequence, that all horizontal restraints are now analyzed through application of some form

rule leads to lower output and, consequently, higher prices for the services provided by the association as a whole.

Langenfeld and Morris show further that there is no reason to expect new competition to solve the resulting competitive problem. Free entry into the association does not force down the market price when all new entrants must adhere to the cost-raising rules that incumbent competitors must follow. Association membership typically confers substantial benefits (for example, access to multiple listing service real estate listings, or quality certification through membership in a respected professional organization), so entrants do not choose the alternative of selling services without association membership.

Langenfeld and Morris point out that this "raising rivals' costs" interpretation of association rules is predicated on the absence of close competitors for the services provided by association members (i.e., the association must constitute an antitrust market). They also emphasize that the same rules that may permit the exercise of rnarket power may also generate socially valuable efficiencies. Nevertheless, association rules can have harmful consequences for competition, so they are appropriate subjects for antitrust review.

2 Denis, Focusing on the Characterization of Per Se Unlawful Restraints, 36 ANTITRUST BULL. 641 (1991).

3441 U.S. 1 (1979).

4468 U.S. 85 (1984). 
of the rule of reason..$^{5}$ Remarkably, after a century of judicial experience analyzing horizontal restraints under the Sherman Act, the legal rules under which they are reviewed remain in dispute.

I. The emperor has no clothes: on the judicial methodology for creating per se rules

Even if the antitrust community could agree on the list of practices antitrust law should proscribe, were it always possible and sensible to conduct a case-by-case analysis, the task of specifying the rules courts should apply would be incomplete without resolving how to formulate the legal rule. The latter task cannot be undertaken without first answering the general question: When should antitrust law ask a court to declare business practices illegal without a full-scale factual investigation of their effect under the rule of reason, as through application of a per se rule?

This question is far from academic. Since 1977, one plausible year for dating the start of the antitrust's Chicago school revolution, ${ }^{6}$ much judicial effort has been spent reconsidering per se categories in the law of horizontal restraints. Yet even a casual review of the leading cases calls into question whether courts have a completely coherent theory of when to create rules that structure what would otherwise be a rule of reason analysis. ${ }^{\text {? }}$

5 Muris, The New Rule of Reason, 57 AnTitrust L.J. 859 (1989); see Easterbrook, The Limits of Antitrust, 63 Texas L. Rev. 1, 19 (1984) ("Under NCAA the defendant may offer an economic justification even of a 'naked' restraint").

6 In 1977, the Supreme Court decided Continental T.V., Inc. v. GTE Sylvania, Inc., 433 U.S. 36 (1977). For descriptions of the changes wrought by the Chicago school revolution, see Calvani \& Silbarium, Antitrust Today: Maturity or Decline, 35 AnTrTrust Bull. 123 (1990); Baker, Recent Developments in Economics That Challenge Chicago School Views, 58 ANTITRUst L.J. 645, 645 n.1 (1989); Baker, Book Review, 34 ANTITRUST BULl. 919 (1989).

7 Moreover, this procedural question has obvious substantive consequences. As Denis emphasizes, "characterization of a practice as subject to the per se rule means that the plaintiff is more likely to win the case." Supra note 2, at 644 . 
One reason courts appear unsettled in analyzing this important doctrinal area is that many of the categories themselves are in flux. In the past decade and a half, for example, the Supreme Court has felt free to overrule a per se rule, ${ }^{8}$ qualify another, ${ }^{9}$ and narrow a third. ${ }^{10}$ In addition, courts and commentators have created a dazzling variety of "structured inquiries" and "quick look" approaches to circumscribe the factual inquiry required by a fullblown analysis of reasonableness. The Supreme Court has instructed that tying may be proscribed without a full rule of reason analysis if, after characterization of the conduct as tying, a court also finds coercion or forcing; 11 group boycotts may be proscribed without a full rule of reason analysis if, after characterization of the conduct as a group boycott, a court also finds market power, ${ }^{12}$ and horizontal price fixing may be proscribed without a full rule of reason analysis if, after characterization of the conduct

8 GTE Sylvania (overruling U.S. v. Arnold, Schwinn \& Co., 388 U.S. 365 (1967)).

$9 \quad B M I$ (a per se prohibition does not always apply to price fixing).

10 Business Electronics Corp. v. Sharp Electronics Corp., 485 U.S. 717 (1988) (narrowing the per se prohibition of vertical price fixing). The per se rule against group boycotts may also have been narrowed. FTC $v$. Indiana Federation of Dentists (IFD), 476 U.S. 447, 458 (1986) (distinguishing instant case because the per se prohibition of group boycotts is "limited to cases in which firms with market power boycott supplies or customers in order to discourage them from doing business with a competetitor").

11 Jefferson Parish Hospital Dist. No. 2 v. Hyde, 466 U.S. 2 (1984). Although the per se violation has long been thought to require both proof of coercion or forcing and proof of market power after characterization, see ABA Antitrust Section, Antitrust Law Developments 81-88 (2d ed. 1984), in Jefferson Parish these separate requirements may have been collapsed. Jefferson Parish, 466 U.S. at 12-18.

12 Northwest Wholesale Stationers, Inc. v. Pacific Stationery \& Printing Co., 472 U.S. 284 (1985). In addition, per se analysis of group boycotts must be predicated on a showing that the purpose of the boycott is to discourage customers or suppliers from doing business with a competitor. IFD, 476 U.S. at 458. 
as horizontal price fixing, no new product is created. ${ }^{13}$ The Federal Trade Commission prohibits horizontal restraints without undertaking a full analysis of their reasonableness if the practice is inherently suspect and if no efficiency justification is plausible. ${ }^{14}$ Judge Easterbrook has proposed that courts apply "filters" to screen horizontal restraints, ${ }^{15}$ and the Justice Department has endorsed a "quick look" approach of its own.16 While these rules require something more than an unstructured rule of reason, they deviate from the traditional per se approach because they do not require courts to cease their factual inquiry and find a violation once the practice is found to fit the category. ${ }^{17}$

Perhaps the most important reason that courts appear to be unsettled in performing horizontal restraints analysis is that the justifications the Supreme Court routinely provides for creating per se rules are unconvincing explanations for the use of structured inquiries. The Court has stated repeatedly that per se rules are created in order to reduce litigation costs and increase business certainty about forbidden conduct, and that they are applied only to conduct that is manifestly and plainly anticompetitive. ${ }^{18}$

13 BMI; see NCAA, 468 U.S. at 101, 109-110 (proof of market power is not necessary to condemn the practice); cf. IFD, 476 U.S. at 460-61 (market power is a "surrogate for detrimental effects").

14 Massachusetts Board of Registration in Optometry, 110 F.T.C. 549 (1988); cf. NCAA, 468 U.S. at $104 \& 104 \mathrm{n} .2$ (treating per se rule as establishing a presumption); see Muris, supra note 5. The Mass. Board approach is discussed in detail in Langenfeld \& Morris, supra note 1.

15 Easterbrook, supra note 5, at 14.

16 U.S. Department of Justice Antitrust Enforcement Guidelines for International Operations, reprinted in 4 Trade Reg. Rep. $(\mathrm{CCH})$ \ 13,109, at 29,594 (1988).

17 The structured inquiry involving presumptions and burden-shifting suggested by the Court in NCAA, 468 U.S. at 113, is reminiscent of the structured inquiry previously applied by the Court to one common type of horizontal restraint: horizontal mergers. U.S. v. Philadelphia National Bank, 374 U.S. 321 (1963).

18 See, e.g., Arizona v. Maricopa County Medical Society, 457 U.S. 332, 343-44 (1981); GTE Sylvania, 433 U.S. at 50 n.16; NCAA, 435 U.S. at 692. This explanation is accepted by Denis, supra note 2, at 645-46, and by Langenfeld \& Morris, supra note 1 , at 667. 


\section{8 : The antitrust bulletin}

Yet the business certainty and litigation cost reduction benefits of per se rules are easy to overstate. The fight over characterization-determining whether the conduct is in the appropriate pigeonhole ${ }^{19}$ - can involve as much cost, and generate as little business certainty, as a full-blown analysis of reasonableness. ${ }^{20}$ Moreover, the Court undermines its own contention that structured inquiries are invoked only when practices are clearly anticompetitive with its constant questioning of that position, as through the following statements: "there is often no bright line separating per se from rule of reason analysis . . .,"21 "easy labels do not always supply ready answers,"22 and "[e]xactly what types of activity fall within the forbidden category is . . . far from certain." 23 Similarly, the Court has remarked that the distinctions it must make in order to determine whether to use a per se rule are "reasonably clear [in theory]" but "often . . . difficult to apply in practice." 24 These admissions undercut the stated judicial efficiency rationale for per se rules. ${ }^{25}$ Thus, by admitting that it

19 As part of the battle over characterization, defendants seeking to avoid per se treatment may also argue that in the event the practice is found to be within a per se category, it would be appropriate to create an exception to the per se rule. Litigation over this contention adds to the expense and uncertainty of the characterization fight.

20 See BMI, 441 U.S. at 9 (characterization is "not always . . . a simple matter"). The $B M I$ Court rejected as simplistic and overbroad a literal approach of identifying practices subject to per se treatment by simply asking whether competitors had "fixed" a "price." Id. at 9. The Court admitted that it must analyze "the effect and . . . the purpose of the practice" to characterize it, $i d$. at 19 , though it contended that this scrutiny is less "burdensome" than a rule of reason analysis because it is undertaken "facially" and only after "considerable [judicial] experience" with the practice. Id. at $19 \& 19$ n.33.

$21 \quad N C A A, 468$ U.S. at 104 n.26.

$22 \quad B M I, 441$ U.S. at 8.

23 Northwest Wholesale Stationers, 284 U.S. at 294.

24 Monsanto Co. v. Spray-Rite Service Corp., 465 U.S. 752, 762 (1984).

25 When the probable judicial outcome of a lawsuit is evident to the parties before litigation begins, the controversy is likely to be settled before trial. For this reason, those disputes reaching trial will on average be those with the most uncertain outcomes, regardless of the legal rules 
experiences a pervasive uncertainty about the bounds of structured inquiries, and serious difficulty in applying per se categories, the Supreme Court calls into question its own explanations for its use of per se rules.

\section{Structured inquiries after the rise of the Chicago school}

In retrospect, the 1950's and 1960's could be called the "golden age" of the antitrust per se rule. ${ }^{26}$ Not coincidentally, these were the years during which antitrust thinking was characterized by a consensus around the structural model. ${ }^{27}$ The Supreme Court embedded the structural model in the per se rules of the earlier era, in order to give lower courts, lawyers, and enforcers signposts to follow as they work through the implications of that consensus for identifying the legal rules that will be employed in individual cases. ${ }^{28}$ The renewed interest in structured inquiries today most likely reflects the development of a new consensus around the economic approach to antitrust pioneered by

employed to decide them. Even taking into account this selection bias, the Supreme Court's remarkable series of admissions appear to reflect a genuine difficulty with characterization under the per se rule.

26 E.g., Northern Pac. Ry. v. U.S., 356 U.S. 1 (1985) (tying); White Motor Co. v. U.S., 372 U.S. 253 (1963) (territorial and customer restraints on distributors); U.S. v. Arnold, Schwinn \& Co., 388 U.S. 365 (1967) (exclusive distribution territories). One commentator observes that before 1977, "case after case instructed us that there was an everwidening category of plainly anticompetitive practices that could not be justified, no matter how reasonable--[the per se rule] was in the ascendancy." Malina, Antitrust in the Supreme Court-1988, at 57 ANTrrRust L.J. 257, 257-58 (1988).

27 Baker, Book Review, supra note 6 . According to the structural model, the exercise of market power is rendered more likely by increases in market concentration.

28 Under this theory, antitrust per se rules simplify the intellectual task of identifying the rule that is to be applied, without reducing the costs of determining whether a rule has been violated. Their advantage is in helping judges and lawyers identify the rule that will apply to a case, not in reducing litigation costs or improving business certainty about the judical treatment of firm conduct. 
the Chicago school. ${ }^{29}$ But the precise formulation of rules that describe the new consensus is the subject of debate. ${ }^{30}$

29 From a law and economics perspective, per se rules may be preferred to a rule of reason when violations are expensive for a court to observe but are strongly correlated with observable behaviors that are cheaply observed, and when it would be expensive for a violator to break the law without engaging in the observable behavior. Under such circumstances, the judicial system would minimize enforcement costs by conditioning liability on the cheaply observable behavior, and the resulting enforcement errors, corporate compliance costs, and social costs of deterring socially beneficial actions, would not produce a substantial efficiency loss.

From this perspective, the current ferment in the law of horizontal restraints involves an attempt to identify certain behaviors-readily observable and nonmanipulable correlates of harmful conduct-on which to condition legal liability. Unfortunately, the behaviors that have been proposed may be nearly as costly to observe as the violation itself.

Market power, an obvious candidate as a building block for per se rules, is a troublesome concept because, while market share is typically observable given a market definition, the link between market share and market power is contested. See Demsetz, Two Systems of Belief About Monopoly, in Industrial Concentration: The New Learning (H. Goldschmid, H.M. Mann, \& J.F. Weston, eds. 1974); cf. U.S. v. Aluminum Co. of America, 148 F.2d 416 (2d Cir. 1945) (a high market share may reflect superior skill and industry, or market power).

Recently, the $B M I$ majority has proposed the creation of a new product or large efficiency as a readily observable behavior on which a per se rule could be based. The $B M I$ dissent, however, exposed the practical difficulties of observing the behavior on which application of the proposed structured inquiry is conditioned by presenting evidence that the horizontal restraint created neither a new product nor a large efficiency unavailable without the restraint. 441 U.S. at 30 (describing the competitive market for film "synch" rights).

30 So long as the primary debate among judges and commentators concerns the best way to formulate legal rules in order to reflect Chicago school understandings, the main judicial task is to rationalize the precedents of the last 15 years through the creation of structured inquiries. But to the extent new developments in economics transform or undermine mainstream views about antitrust, see Baker, Recent Developments in Economics That Challenge Chicago School Views, supra note 6, 645 n.1, per se rules reflecting Chicago school thinking may be called into question. 
The current debate over the proper formulation of per se rules applying to horizontal restraints began when the Supreme Court decided $B M I$, over a decade ago. In that decision the Court, influenced by the new economic analysis, recognized that the large efficiencies created by the horizontal restraint under review made it inappropriate to apply the longstanding per se prohibition. Although the Court has analyzed horizontal restraints several times since it decided $B M I,{ }^{31}$ it remains unclear whether the $B M I$ exception applies only when efficiencies are so large that it is as if a new product has been created, ${ }^{32}$ whether $B M I$ mandates a complex structured inquiry of the form suggested by the antitrust enforcement agencies, ${ }^{33}$ or whether $B M I$ requires an unstructured reasonableness analysis. ${ }^{34}$

Denis argues that recent precedents are consistent with the most conservative interpretation of $B M I$ - that $B M I$ does no more than create a new product exception. Under this rule, a horizontal practice that threatens market power on its face will not receive rule of reason review unless the practice plausibly leads to a substantial efficiency manifested in the creation of a new product; otherwise, the practice is prohibited without examining its reasonableness. Langenfeld and Morris, in contrast, accept the FTC

31 The most recent decisions are Palmer v. BRG of Georgia, Inc., 111 S. Ct. 401 (1990); FTC v. Superior Court Trial Lawyers Assoc., 110 S. Ct. 768 (1990).

32 Accord, NCAA at 101, 103; cf. Denis, supra note 2, at 649 (the $B M I$ exception requires that the price restraint create both a new product and genuine economic integration).

33 Mass. Board (FTC policy); U.S. Department of Justice Antitrust Enforcement Guidelines for International Operations, supra note 16 (DOJ policy). The $B M I$ Court pointed out that mergers and joint ventures comprise another class of horizontal restraints that are not considered illegal per se. $B M I, 441 \mathrm{~S}$. Ct. at 23 . These restraints are instead subject to a structured inquiry under the rule of reason pursuant to Clayton Act $\$ 7$, Philadelphia National Bank, and to similar standards under Sherman Act § 1 .

${ }^{34} C f$. Muris, supra note 5 (all horizontal restraints are now reviewed under the rule of reason, although the reasonableness review is structured and circumscribed for those practices that are inherently suspect). 
view that $B M I$ and its descendants require a structured inquiry more complex than those envisioned by older per se rules. Under this approach, a horizontal practice that threatens market power on its face will be reviewed under the rule of reason merely on a showing that a substantial efficiency justification is plausible, regardless of whether that efficiency takes the form of the creation of a new product.

At stake in this dispute is the treatment of horizontal agreements involving price that generate substantial efficiencies without creating new products. These practices may include many of the association rules addressed by the model of Langenfeld and Morris. ${ }^{35}$ Such horizontal restraints threaten to facilitate the exercise of market power, but they may simultaneously offer benefits to consumers and producers and they do not necessarily involve the creation of new products. ${ }^{36}$ They would receive per se rule treatment under the narrow interpretation of $B M I$, and rule of reason treatment under a broader view.

If economic efficiency is the Chicago school lodestar, as is frequently suggested, the interpretation of $B M I$ limiting the exemption from the per se rule to horizontal restraints that create new products seems too narrow. A less tendentious view of the new mainstream consensus, sweeping beyond Chicago school partisans, is that vertical restraints and nonprice restraints tend to be procompetitive, while horizontal restraints

35 Potential efficiency justifications for horizontal restraints among real estate brokers, for example, are cataloged in Lopatka \& Simons, Real Estate Multiple Listing Services and Antitrust Revisited in Electronic Servicis Networks: A Business and Public Policy Challenge (M. Guerin-Calvert \& S. Wildman, eds. 1991).

36 In the leading work clarifying the implications of the Chicago school approach to antitrust for legal doctrine, Judge Bork emphasized that price-fixing agreements are frequently ancillary to efficiency-enhancing economic integration. R. BORK, THE ANTITRUsT Paradox 263-79 (1978). 
and restraints bearing on price tend to be anticompetitive. ${ }^{37}$ If this alternative view is correct, the narrow interpretation of $B M I$ will likely persist. ${ }^{38}$

37 From a less interventionist perspective, this generalization understates the extent to which horizontal practices may create beneficial efficiencies. From a more interventionist perspective, this generalization understates the extent to which vertical practices may harm competition, as by creating market power through "raising rivals' costs."

38 From a law and economics perspective, in contrast, the choice between the two interpretations turns on the observation expense and manipulability of the alternative criteria for removing a horizontal restraint on price from a per se prohibition. See supra note 29. The narrow interpretation of $B M I$, that a new product is required, will persist if new products created by price restraints are more cheaply observable than the wider requirement of an economic integration, and if firms seeking to exercise market power are less capable of evading per se treatment by creating the misleading appearance of satisfying the former standard than the latter one. 